\title{
$\mathrm{ABO}$ 부적합 신 이식 전 치료적 혈장교환술 횟수의 예측 변수로서의 초기 $\mathrm{ABO}$ 항체 역가
}

\author{
김지은 ${ }^{1} \cdot$ 김신영 ${ }^{1} \cdot$ 김명수 $^{2,3} \cdot$ 김유선 ${ }^{2,3} \cdot$ 김현옥 ${ }^{1}$ \\ 연세대학교 의과대학 진단검사의학교실 ${ }^{1}$, 외과학교실 ${ }^{2}$, 장기이식연구소 ${ }^{3}$
}

\section{Initial ABO Antibody Titer as a Variable for Estimating Number of Therapeutic Plasma Exchange prior to ABO Incompatible Kidney Transplantation}

\author{
Jieun Kim ${ }^{1}$, Sinyoung Kim ${ }^{1}$, Myoung Soo Kim ${ }^{2,3}$, Yu Seun $\mathrm{Kim}^{2,3}$, Hyun Ok Kim ${ }^{1}$ \\ Departments of Laboratory Medicine ${ }^{1}$ and Surgery ${ }^{2}$, Research Institute for Transplantation ${ }^{3}$, Yonsei University College of Medicine, Seoul, \\ Korea
}

Background: Therapeutic plasma exchange (TPE) for desensitization in ABO incompatible kidney transplantation (KT) has raised concerns regarding efficiency and safety. The purpose of this study was to determine the number of TPE prior to KT required to reach target titer for $\mathrm{KT}$ according to $\mathrm{ABO}$ blood groups.

Methods: The distribution of $\mathrm{ABO}$ antibody $(\mathrm{Ab})$ titer of 117 patients was investigated. The relationship between initial $\mathrm{ABO} \mathrm{Ab}$ and number of TPEs required to reach target titer to $\leq 1: 8$ prior to $\mathrm{KT}$ was evaluated retrospectively according to blood groups and $\mathrm{ABO} \mathrm{Ab}$ classes.

Results: The initial IgG ABO Ab titers were the highest in blood $\mathrm{O}$ group recipients, and the average number \pm standard deviations (range) of TPEs performed prior to ABO incompatible KT was $3.0 \pm 1.1(0 \sim 5)$ in blood group A, $3.7 \pm 1.5(0 \sim 8)$ in blood group $B$, and $5.3 \pm 1.9(2 \sim 13)$ in blood group $\mathrm{O}$, respectively. The best correlation was observed in the linear relationship between initial $\mathrm{ABO} A b$ titer and number of TPEs required $\left(\mathrm{y}=0.6829 \mathrm{x}^{+}\right.$ $0.0523, \mathrm{R}^{2}=0.946, \mathrm{x}=\log _{2}$ initial $\mathrm{ABO} \mathrm{Ab}$ titer, $\mathrm{y}=$ number of TPE required), regardless of the specific $\mathrm{ABO}$ blood group.

Conclusion: The number of TPEs can be highly deduced from initial ABO Ab titer and our developed equation in desensitization programs would help increase the efficiency of TPE and patient safety. (Korean J Blood Transfus 2016;27:22-30)

Key words: Plasma exchange, Blood group incompatibility, Kidney transplantation, ABO antibodies

@) This is an Open Access article distributed under the terms of the Creative Commons Attribution Non-Commercial License (http://creativecommons.org/licenses/by-nc/4.0) which permits unrestricted non-commercial use, distribution, and reproduction in any medium, provided the original work is properly cited. 


\section{Introduction}

ABO-incompatible kidney transplantation (iABO KT) has expanded the donor pool by increasing the availability of transplantable organs, decreasing the waiting period. The blood type barrier is a major obstacle to the naturally occurring anti-A or anti-B, which cause hyperacute rejection in preliminary cases, by not removing them from the circulation at the time of transplantation. ${ }^{1)}$ Therapeutic plasma exchange (TPE) before an iABO KT may be used to prevent hyperacute rejection, and posttransplantation TPE is often used to treat antibody-mediated rejection that occurs in this setting. ${ }^{2)}$

Currently, most courses of desensitization include TPE followed by intravenous immunoglobulin (IVIG) as a preconditioning and medication of thymoglobulin, tacrolimus, mycophenolate mofetil, and steroids as an immunosuppressant worldwide. ${ }^{3)}$ TPE, one of several immunomodulating techniques, plays an important role by removing IgG and IgM ABO antibody $(\mathrm{Ab})$ in $\mathrm{iABO} \mathrm{KT}$.

TPE to permit iABO KT has been successfully performed at several centers in Korea and is currently an American Society for Apheresis Category II indication. ${ }^{4)}$ Albumin is the most commonly used replacement fluid for TPE. The procedure cost of TPE including the charge of albumin as replacement fluid is 740,000 Korean won per one exchange in Korea. However, only a limited number of plasma exchanges is covered by Korean medical insurance. ${ }^{5)}$ In the United States, the cost is $\$ 5,925$ per one exchange, only including base inputs without facility and side effect costs. ${ }^{\text {.) }}$ Although the major adverse effects of TPE, such as symptomatic hypocalcemia, hypotension, urticaria, and nausea, occur in approximately $4 \%$ of procedures, long-lasting immunosuppression may lead to hazardous clinical consequences, such as persistent lymphopenia, increased risk of infection, or viral reactivation. ${ }^{7-9)}$

A review of our TPE program for iABO KT is necessary to determine whether it is efficient and reasonable because individual institutions use their own innate $\mathrm{Ab}$ removal programs. The Johns Hopkins group uses a schedule for the number of planned pre- and posttransplant TPE treatments based on pre-TPE IgG titer based on a goal ABO Ab titer of $\leq 16$, whereas the Royal Melbourne Hospital group uses a goal $\mathrm{ABO} \mathrm{Ab}$ titer of $8 \sim 32$ depending on the titration method. ${ }^{10,11)}$

The substance removal kinetics of TPE is known to be exponential based on a several compartment models, and post-exchange events with optimal intervals between the procedures have been developed. ${ }^{12)}$ The objective of our study was to define the number of TPEs according to initial $\mathrm{ABO} \mathrm{Ab}$ titers to guide clinicians in the design of ideal strategies for patients preparing $\mathrm{iABO} \mathrm{KT}$.

\section{Materials and Methods}

\section{Patients}

One hundred seventeen end-stage renal disease patients, excluding two outlier patients among 119 patients, with negative pre-transplant lymphocyte cross match test who had undergone iABO KT at Severance Hospital between June 2010 and July 2015 were included in this study. The relationship of initial $\mathrm{ABO} \mathrm{Ab}$ titer and the number of TPEs re- 
quired to reach post-TPE $\mathrm{Ab}$ titer to $\leq 1: 8$ prior to kidney transplantation was retrospectively evaluated according to their blood groups and $\mathrm{ABO} \mathrm{Ab}$ classes. Clinical and laboratory data were extracted from our electronic database and the patient's medical records.

\section{Pre-transplantation conditioning}

All patients underwent the pre-transplantation conditioning protocol that consists of TPE followed by IVIG $(100 \mathrm{mg} / \mathrm{kg})$ and immunosuppressants $(0.1$ $\mathrm{mg}$ /day tacrolimus, $1500 \mathrm{mg} /$ day mycophenolate, 20 $\mathrm{mg}$ /day prednisone, $375 \mathrm{mg} / \mathrm{m}^{2}$ rituximab) administration. All patients received pre-transplantation conditioning prior to the operation. TPE was conducted using the COBE spectra system (Terumo BCT, Lakewood, CO, USA) mostly for patients who had $\mathrm{ABO} \mathrm{Ab}$ titers greater than 1:8. One plasma volume was removed from each patient and $100 \%$ replacement was provided using a 5\% albumin solution (Green Cross, Yongin, Korea) or fresh frozen plas- ma (FFP) of the AB blood group. TPE and IVIG treatments were conducted every other day before transplantation until both $\operatorname{IgM}$ and IgG titers were no greater than $1: 8$ in most cases. TPE was performed using 5\% albumin solution for the initial sessions, and the last 2 sessions of TPE were carried out with the $\mathrm{AB}$ blood group FFP to prevent bleeding before transplantation. Immunosuppressive drugs were used before transplantation to prevent graft rejection. Administration of tacrolimus, mycophenolate, and prednisone was initiated 7 days prior to transplantation, and rituximab was administered 2 days before transplantation after performing TPE. ${ }^{13,14)}$

\section{Measurement of $A B O$ antibody titers}

$\mathrm{ABO} \mathrm{Ab}$ titers were determined by the tube method, testing two-fold serial dilutions of the patients' serum with commercially available $\mathrm{A} / \mathrm{B}$ indicator red cells using 3.0\% Affirmagen (Ortho Clinical Diagnostics, Raritan, NJ, USA). After incubation at room temperature for $30 \mathrm{~min}$ and centrifugation at

Table 1. Distribution of recipient-donor $\mathrm{ABO}$ type and $\mathrm{ABO}$ antibody titers

\begin{tabular}{|c|c|c|c|c|c|c|}
\hline \multicolumn{2}{|c|}{ Blood group } & \multicolumn{4}{|c|}{ Anti-A or Anti-B titer } & \multirow{3}{*}{ No. of cases $(\%)$} \\
\hline \multirow{2}{*}{ Recipient } & \multirow{2}{*}{ Donor } & \multicolumn{2}{|c|}{ IgG } & \multicolumn{2}{|c|}{ IgM } & \\
\hline & & Anti-A & Anti-B & Anti-A & Anti-B & \\
\hline $\mathrm{O}$ & A & $4 \sim 512$ & - & $8 \sim 512$ & - & $18(15.1)^{*}$ \\
\hline $\mathrm{O}$ & $\mathrm{AB}$ & $32 \sim 128$ & $16 \sim 64$ & 32 & $16 \sim 64$ & $3(2.5)$ \\
\hline $\mathrm{O}$ & B & - & $8 \sim 1,024$ & - & $8 \sim 128$ & $18(15.1)^{*}$ \\
\hline A & $\mathrm{AB}$ & - & $\leq 2 \sim 128$ & - & $4 \sim 256$ & $14(11.8)$ \\
\hline $\mathrm{A}$ & B & - & $\leq 2 \sim 64$ & - & $4 \sim 64$ & $21(17.6)$ \\
\hline $\mathrm{B}$ & $\mathrm{AB}$ & $\leq 2 \sim 64$ & - & $4 \sim 128$ & - & $24(20.2)$ \\
\hline $\mathrm{B}$ & A & $2 \sim 128$ & - & $4 \sim 128$ & - & $21(17.6)$ \\
\hline Total & & & & & & $119(100.0)$ \\
\hline
\end{tabular}

*One outlier patient was included. 
$3400 \mathrm{rpm}$ for 15 seconds, the highest serum dilution ratio showing $1+$ reactivity by indicated the $\mathrm{ABO}$ $\mathrm{Ab}$ titers was identified. IgG titers were measured using serum samples treated with $0.01 \mathrm{M}$ dithiothreitol solution (Sigma-Aldrich, St. Louis, MO, USA), while IgM titers were determined from un-

A

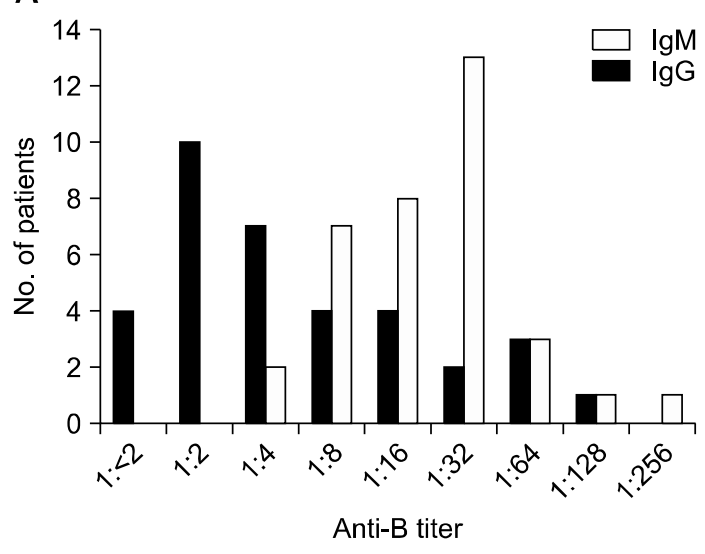

C

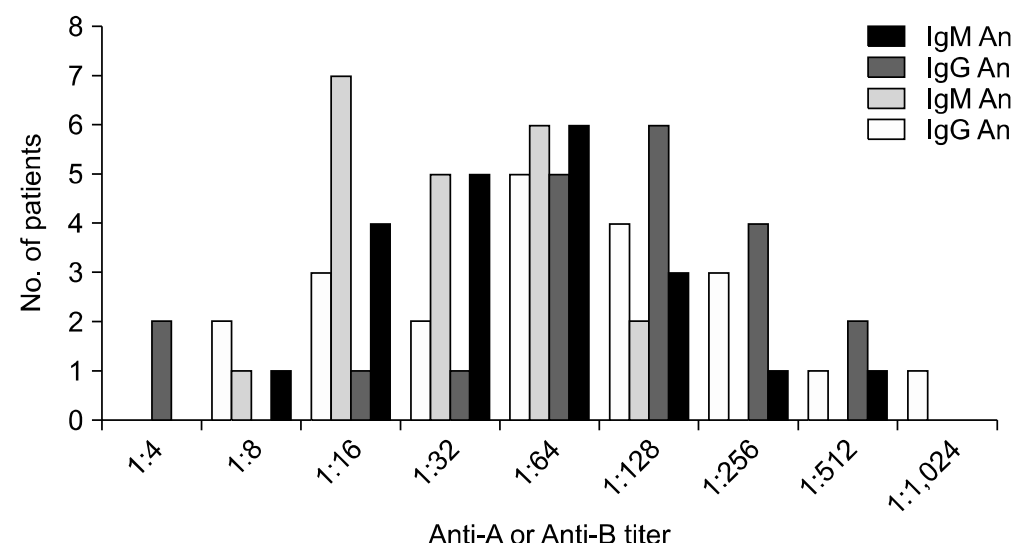

Anti-A or Anti-B titer treated samples. ${ }^{2)}$ Antibody titers were evaluated every day after initiation of the conditioning protocol while preparing for transplantation. The initial ABO $\mathrm{Ab}$ variable used in the correlation analysis is defined as an $\mathrm{IgG}, \mathrm{IgM}$ and higher $\mathrm{Ab}$ titer between $\mathrm{IgG}$ and $\mathrm{IgM}$ classes before the initiation of $\mathrm{Ab}$ depletion.

B

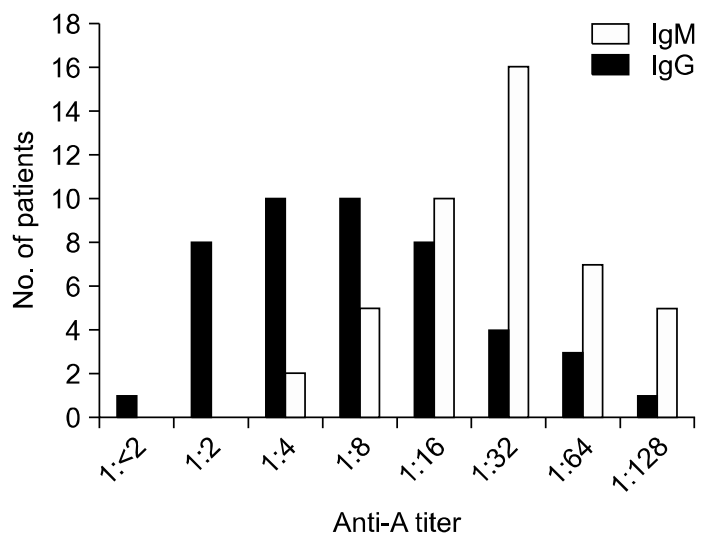

Fig. 1. Distribution of initial $A B O$ antibody titer of recipients according to blood group. (A) Distribution of blood group A recipients, (B) $\mathrm{B}$ recipients, and (C) $\mathrm{O}$ recipients. The initial $\mathrm{ABO}$ Ab titers of blood group $\mathrm{O}$ recipients were significantly higher in the case of $\mathrm{IgG}$, compared to both blood group A and blood group B recipients $(P<0.001)$, whereas in the case of $\operatorname{IgM}$, only ABO Ab titers of blood group $\mathrm{O}$ recipients were significantly higher compared to blood group A recipients $(P=0.040)$. 


\section{Statistical analysis}

The two-sample t-test was used to compare $\mathrm{ABO}$ $\mathrm{Ab}$ titers ( $\log _{2}$ initial $\mathrm{ABO} \mathrm{Ab}$ titer) among the blood groups with SPSS software (version 23.0; SPSS Inc., Chicago, IL, USA), and a two-tailed value of $P<0.05$ was considered statistically signifi cant. The value of $\mathrm{R}^{2}$ (coefficient of determination) was calculated by using Microsoft Excel 2010 (Microsoft Corporation, Richmond, WA, USA).

\section{Results}

\section{Patients}

Among the total of 117 patients, 80 patients were male $(68.4 \%)$ and the median age of the patients was 46 years (interquartile range $37 \sim 53$ years). Transplantation from $\mathrm{AB}$ donors to $\mathrm{B}$ recipients $\mathrm{AB}$ $\rightarrow \mathrm{B}), \mathrm{A} \rightarrow \mathrm{B}$, and $\mathrm{B} \rightarrow \mathrm{A}$ were majority pair combinations including approximately $19.7 \%, 17.9 \%$, and $17.1 \%$ of the population, respectively, and three cases $(2.6 \%)$ of $\mathrm{AB} \rightarrow \mathrm{O}$ were performed (Table 1$)$.

\section{Initial $A B O$ antibody and $T P E$}

The distribution of initial $\operatorname{IgG}$ or $\operatorname{IgM} \mathrm{ABO} A b$ titer is illustrated according to recipients' blood types (Fig. 1).

The initial $\mathrm{ABO} \mathrm{Ab}$ titers of blood group $\mathrm{O}$ recipients were significantly higher in case of $\mathrm{IgG}$, compared to both blood group A and blood group B recipients $(P<0.001)$, whereas in case of $\operatorname{IgM}$, ABO $\mathrm{Ab}$ titers of blood group $\mathrm{O}$ recipients were only significantly higher compared to blood group A recipients $(P=0.040)$.

The average number \pm standard deviation (range) of TPEs performed prior to iABO KT was 3.0 \pm 1.1 $(0 \sim 5)$ in blood group A, $3.7 \pm 1.5(0 \sim 8)$ in blood group $\mathrm{B}$, and $5.3 \pm 1.9(2 \sim 13)$ in blood group $\mathrm{O}$ recipients, respectively. While most transplantations proceeded at an $\mathrm{ABO} \mathrm{Ab}$ titer of 1:8, 11 patients (9.4\%) with IgG or IgM titers not lower than 1:16 underwent $\mathrm{iABO} \mathrm{KT}$, including nine blood group $\mathrm{O}$ recipients (five $\mathrm{A} \rightarrow \mathrm{O}$ and four $\mathrm{B} \rightarrow \mathrm{O}$ cases) and two blood group $\mathrm{B}$ recipients (one $\mathrm{A} \rightarrow \mathrm{B}$ and one $\mathrm{AB} \rightarrow$ B case).

The correlation between the initial $\mathrm{ABO} \mathrm{Ab}$ titer of $\mathrm{IgG}, \mathrm{IgM}$ and higher $\mathrm{Ab}$ titer between $\operatorname{IgG}$ and

Table 2. Correlations between initial ABO antibody titer and number of TPEs

\begin{tabular}{|c|c|c|c|c|c|}
\hline \multicolumn{2}{|c|}{ Blood group } & \multirow{2}{*}{$\mathrm{ABO}$ antibody } & \multicolumn{3}{|c|}{$\mathrm{R}^{2}$} \\
\hline Recipient & Donor & & IgG & $\operatorname{IgM}$ & $\operatorname{IgG}$ or $\operatorname{IgM}$ \\
\hline $\mathrm{O}$ & $\mathrm{B}, \mathrm{AB}$ & Anti-B & $0.831^{*}$ & 0.7017 & $0.8855^{\star}$ \\
\hline $\mathrm{O}$ & $\mathrm{A}, \mathrm{AB}$ & Anti-A & $0.8414^{*}$ & 0.0581 & $0.8874^{*}$ \\
\hline A & $\mathrm{B}, \mathrm{AB}$ & Anti-B & 0.6525 & 0.8484 & 0.7919 \\
\hline $\mathrm{B}$ & $\mathrm{A}, \mathrm{AB}$ & Anti-A & 0.5044 & 0.7924 & 0.65 \\
\hline
\end{tabular}

*The four correlations which showed the best fit in linear relationship. 
IgM classes and the number of TPEs observed mostly showed an exponential relationship ( $x=\log _{2}$ initial $\mathrm{ABO} \mathrm{Ab}$ titer, $\mathrm{y}=$ number of TPE required), excluding four circumstances when the recipient was $\mathrm{O}$ blood type, calculated with IgG and higher Ab titer between IgG and IgM classes (Table 2). However, the best correlation between the initial $\mathrm{ABO} \mathrm{Ab}$ titer of the higher $\mathrm{Ab}$ titer between $\mathrm{IgG}$ and $\operatorname{IgM}$ classes and the number of TPEs observed showed an linear relationship $\left(y=0.6829 x+0.0523, R^{2}=0.946, x=\log _{2}\right.$ initial $\mathrm{ABO} A b$ titer, $\mathrm{y}=$ number of TPE required), if all the 117 cases were integrated in regardless of recipient's blood type or ABO Ab classes. This can be universally applied in practice, for example, if a

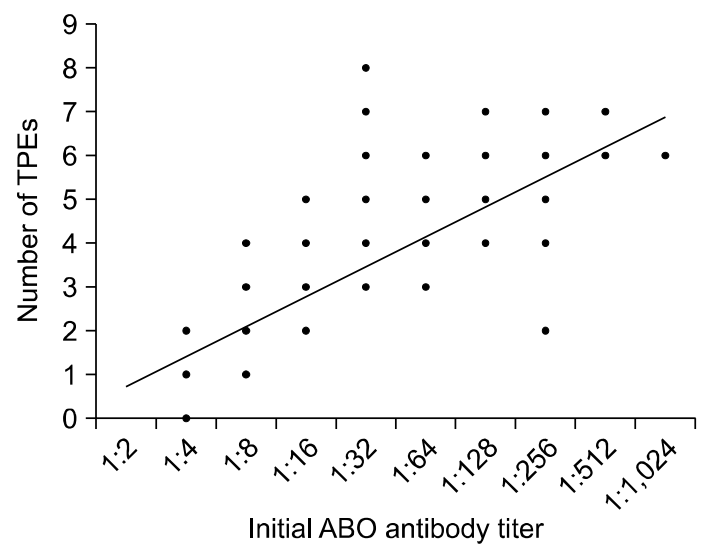

Fig. 2. Relationship between initial $A B O$ antibody titer $(\mathrm{Ab})$ and number of therapeutic plasma exchanges (TPEs). The best correlation between the initial $\mathrm{ABO} \mathrm{Ab}$ titer of the higher $\mathrm{Ab}$ titer between IgG and IgM classes and the number of TPEs observed showed a linear relationship $(y=0.6829 x+$ 0.0523, $\mathrm{R}^{2}=0.946, \mathrm{x}=\log _{2}$ initial $\mathrm{ABO} \mathrm{Ab}$ titer, $y=$ number of TPE required), if all 117 cases were integrated regardless of recipient's blood type or ABO $\mathrm{Ab}$ classes. blood group A recipient had an initial IgG type anti-B with $1: 8$ and $\operatorname{IgM}$ type anti-B with $1: 32$. The $\mathrm{X}$ is 5 (the higher value, 1:32 $\mathrm{IgM}$, transformed to $\log$ base 2) and $y$, the expected number of TPEs for iABO KT, was 3.467 (Fig. 2).

\section{Outlier patients}

Among the 119 cases, two patients had undergone an unexpected number of TPEs, with both patients showing initial $\mathrm{ABO} \mathrm{Ab}$ titers of 1:256. One patient was an blood group $\mathrm{O} 5$-year-old boy who was diagnosed with Wilms' tumor, nephrectomy due to renal failure aggravated by localized solid mass, and had received a kidney from his mother, who was A blood type. Immunosuppressant therapy and two rounds of TPE by using replacement fluids including albumin and FFP, respectively, lowered his titers to 1:4, with a good response to Ab removal.

Another patient was an blood group $\mathrm{O}$ 64-year-old male diagnosed with end-stage renal disease due to prolonged hypertension and a history of chronic hepatitis C. He received a kidney from his daughter, who had a B blood type. Although the pre-conditioning regimen was adopted, his anti-B titer did not decrease easily. A total of 13 rounds of TPE were performed ( 9 albumin and 4 FFP episodes) to lower his titers to $1: 4$, conducted by the addition of eight TPEs to five TPEs, which were more than initially planned.

\section{Discussion}

The findings of our retrospective study confirm that the number of TPEs required to proceed to iABO KT shows an exponential relationship be- 
tween initial $\mathrm{ABO} \mathrm{Ab}$, which was previously reported by Lawrence et al. ${ }^{15)}$ Although his study focused on $\mathrm{IgG} \mathrm{Ab}$ titer, we considered all aspects in $\mathrm{IgG}, \mathrm{IgM}$, and either higher Ab titer of IgG or IgM classes, because there is currently a debate regarding which immunoglobulin class is more potent in the course of rejection. ${ }^{16)}$ In addition, we focused on the correlation according to the recipients' blood group and $\mathrm{ABO} \mathrm{Ab}$ titer, which is critical for graft survival. ${ }^{17)}$ This is the first study to suggest a number of TPEs based on the investigation considering the recipients' specific blood types and ABO Ab class.

As TPE removes substances present intravascularly, it can be expected that removal efficacy is superior in IgM compared to that in IgG or IgA, as the extravascular distribution was found to be $55 \%, 58 \%$, and $22 \%$, respectively. ${ }^{18)}$ The findings of our study in cases of recipient blood groups A and B were consistent with this principle; however, in cases of recipient blood group $\mathrm{O}$, the best correlation was observed when a higher $\mathrm{Ab}$ titer of either $\operatorname{IgG}$ or $\operatorname{IgM}$ classes was applied. ${ }^{19)}$ In addition, as ABO IgM isoagglutinins exist in a greater amount than $\mathrm{IgG}$, the number of TPE may have been affected by this cause. $^{20)}$

Blood group $\mathrm{O}$ recipients had higher $\mathrm{Ab}$ titers than other blood group recipients, especially in IgG isoagglutinin; the maximum levels of $\operatorname{IgG}$ anti-A and anti-B were 1:512 and 1:1024, respectively. This finding is consistent with the observations of previous studies in Korea in that blood group $\mathrm{O}$ individuals generally have high titers against $\mathrm{A}$ or $\mathrm{B}$ blood antigens. $^{21,22)}$

The use of replacement fluid in TPE differs among institutions based on the physiological impact of such fluids. FFP, which contains all coagulation factors in normal concentrations, can minimize bleeding risk prior to operation. In the protocol used by the Johns Hopkins Medical Center, FFP compatible with the donor and recipient is used as the last portion of the replacement fluids after the use of albumin when the patient is at risk of bleeding. ${ }^{10)}$ FFP is associated with a higher risk of hypersensitivity reactions and transmission of viral infections with the supplementation of coagulation factors; however, its use as a replacement fluid is preferred compared to albumin in many cases. ${ }^{23)}$

The strength of this study is that the TPE protocol is universally applied among most cases, as $A B$ type FFP is used in the two last sessions before transplantation after several TPEs with albumin. Therefore, the number of TPEs acquired from our equation can be easily adopted. The clinical importance of immunoglobulin classes is unclear; however, our approach is safe for preserving good allograft outcomes. The Ab titer can be quantified using advanced methodologies, such as flow cytometry or gel techniques, which can provide more accurate correlations. $^{24,25)}$

In conclusion, we suggest that a number of TPEs can be highly deduced from initial $\mathrm{ABO} A \mathrm{~B}$ titers regardless of the specific blood type or $\mathrm{ABO} A \mathrm{~B}$ classes; therefore, can contribute to the reduction in patients' side effects as well as financial costs.

\section{요 약}

배경: $\mathrm{ABO}$ 부적합 신이식시 탈감작을 위해 시 행하고 있는 치료적 혈장교환술의 효율성과 안전 성에 대한 관심이 증가되고 있다. 본 연구에서는 
신이식 전 목표 역가에 도달하는데 필요한 $\mathrm{ABO}$ 혈액형별 치료적 혈장교환술의 횟수에 대해 결정 해보고자 하였다.

방법: $\mathrm{ABO}$ 부적합 신이식을 받은 117 명의 환 자를 대상으로 $\mathrm{ABO}$ 항체의 역가 분포를 조사하 였다. 또한 초기 $\mathrm{ABO}$ 항체의 역가와 이식전 1:8 이하의 목표 역가를 달성하기 위한 치료적 혈장 교환술의 횟수를 각 혈액형 및 $\mathrm{ABO}$ 항체 종류 별로 후향적으로 분석하였다.

결과: 초기 $\mathrm{ABO}$ 항체의 역가는 $\mathrm{O}$ 형 혈액형 수 여자의 $\mathrm{IgG}$ 에서 가장 높은 값을 보였으며, $\mathrm{ABO}$ 부적합 신이식시 치료적 혈장교환술 횟수의 평균

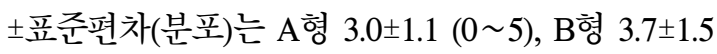
(0 8), 및 $\mathrm{O}$ 형 $5.3 \pm 1.9$ (2 13) 회의 치료적 혈장 교환술이 시행되었다. 또한 초기 $\mathrm{ABO}$ 항체의 역 가와 치료적 혈장교환술의 횟수는 117 명의 $\mathrm{ABO}$ 혈액형에 상관없이 모두 취합하여 계산한 경우 가장 적합한 직선성 관계를 보였다 $(\mathrm{y}=0.6829 \mathrm{x}+$ $0.0523, \mathrm{R}^{2}=0.946, \mathrm{x}=\log _{2}$ 초기 $\mathrm{ABO}$ 항체 역가, $\mathrm{y}=$ 치료적 혈장교환술의 횟수).

결론: 초기 $\mathrm{ABO}$ 항체의 역가를 바탕으로 치료 적 혈장교환술의 횟수를 추정할 수 있었으며 향 후 탈감작 프로그램에서의 본 공식은 치료적 혈 장교환술의 효율성 제고와 환자 안전에 기여하는 데 도움을 줄 것으로 판단된다.

\section{Referencses}

1. Porter KA. Morphological aspects of renal homograft rejection. Br Med Bull 1965;21:171-5

2. Fung MK, Grossman BJ, Hillyer CD, Westhoff CM, American Assocation of Blood Banks. Technical manual. 18th ed. Bethesda, Md: American Association of Blood Banks, 2014; 645-61
3. Tanabe K, Tokumoto T, Ishida H, Ishikawa N, Miyamoto N, Kondo $\mathrm{T}$, et al. Excellent outcome of ABO-incompatible living kidney transplantation under pretransplantation immunosuppression with tacrolimus, mycophenolate mofetil, and steroid. Transplant Proc 2004;36: 2175-7

4. Schwartz J, Winters JL, Padmanabhan A, Balogun RA, Delaney M, Linenberger ML, et al. Guidelines on the use of therapeutic apheresis in clinical practice-evidence-based approach from the Writing Committee of the American Society for Apheresis: the sixth special issue. J Clin Apher 2013;28:145-284

5. Park SJ, Kim SJ, Seo HY, Jang MJ, Oh D, Kim BS, et al. High-dose immunoglobulin infusion for thrombotic thrombocytopenic purpura refractory to plasma exchange and steroid therapy. Korean J Internal Med 2008;23:161-4

6. Heatwole C, Johnson N, Holloway R, Noyes K. Plasma exchange versus intravenous immunoglobulin for myasthenia gravis crisis: an acute hospital cost comparison study. J Clin Neuromuscul Dis 2011;13:85-94

7. Hill JA, Hummel M, Starling RC, Kobashigawa JA, Perrone SV, Arizón JM, et al. A lower incidence of cytomegalovirus infection in de novo heart transplant recipients randomized to everolimus. Transplantation 2007;84: 1436-42

8. Scarsi M, Bossini N, Malacarne F, Valerio F, Sandrini $S$, Airò P. The number of circulating recent thymic emigrants is severely reduced 1 year after a single dose of alemtuzumab in renal transplant recipients. Transpl Int 2010;23: 786-95

9. Bloom DD, Hu H, Fechner JH, Knechtle SJ. T-lymphocyte alloresponses of Campath-1Htreated kidney transplant patients. Transplantation 2006;81:81-7 
10. Tobian AA, Shirey RS, Montgomery RA, Tisch DJ, Ness PM, King KE. Therapeutic plasma exchange reduces $\mathrm{ABO}$ titers to permit $\mathrm{ABO}$ incompatible renal transplantation. Transfusion 2009;49:1248-54

11. Flint SM, Walker RG, Hogan C, Haeusler MN, Robertson A, Francis DM, et al. Successful ABO-incompatible kidney transplantation with antibody removal and standard immunosuppression. Am J Transplant 2011;11:1016-24

12. Kellogg RM, Hester JP. Kinetics modeling of plasma exchange: intra- and post-plasma exchange. J Clin Apher 1988;4:183-7

13. Yoo S, Lee EY, Huh KH, Kim MS, Kim YS, Kim HO. Role of plasma exchange in ABOincompatible kidney transplantation. Ann Lab Med 2012;32:283-8

14. Kim do K, Kim S, Jeong SH, Kim HO, Kim HJ. Therapeutic plasma exchange using the spectra optia cell separator compared with the COBE spectra. Ann Lab Med 2015;35:506-9

15. Lawrence C, Galliford JW, Willicombe $M K$, McLean AG, Lesabe M, Rowan F, et al. Antibody removal before ABO-incompatible renal transplantation: how much plasma exchange is therapeutic? Transplantation 2011;92: 1129-33

16. Won D, Choe W, Kim HJ, Kwon SW, Han DJ, Park SK. Significance of isoagglutinin titer in ABO-incompatible kidney transplantation. J Clin Apher 2014;29:243-50

17. Shin M, Kim SJ. ABO incompatible kidney transplantation-current status and uncertainties. J Transplant 2011;2011:970421
18. Nijkamp FP, Parnham MJ. Principles of immunopharmacology. 3rd ed. Basel: Springer, 2011:271-84

19. Reverberi R, Reverberi L. Removal kinetics of therapeutic apheresis. Blood Transfus 2007;5: 164-74

20. Stussi G, Huggel K, Lutz HU, Schanz U, Rieben R, Seebach JD. Isotype-specific detection of $\mathrm{ABO}$ blood group antibodies using a novel flow cytometric method. Br J Haematol 2005;130:954-63

21. Park ES, Jo KI, Shin JW, Park R, Choi TY, Bang HI, et al. Comparison of total and IgG $\mathrm{ABO}$ antibody titers in healthy individuals by using tube and column agglutination techniques. Ann Lab Med 2014;34:223-9

22. Lee EY, Kim S, Kim HO, Kwon SW, Kim DW, Han KS. Survey analysis of ABO antibody titration at four university hospitals in Korea. Korean J Blood Transfus 2011;22:24-30

23. Laine E, Steadman R, Calhoun L, Blackall D, Levin P, Braunfeld $\mathrm{M}$, et al. Comparison of RBCs and FFP with whole blood during liver transplant surgery. Transfusion 2003;43:322-7

24. Kumlien G, Wilpert J, Safwenberg J, Tydén G. Comparing the tube and gel techniques for $\mathrm{ABO}$ antibody titration, as performed in three European centers. Transplantation 2007;84(12S): s17-9

25. Tanabe K. Interinstitutional variation in the measurement of anti-A/B antibodies: the Japanese ABO-incompatible transplantation committee survey. Transplantation 2007;84(12S):s13-6 